\title{
Excision of Eyelid Tumors: Principles and Techniques
}

\author{
Gangadhara Sundar and Fairooz P. Manjandavida
}

Lesions of the eyelid, benign or malignant, have physical, esthetic and psychological consequences and may on occasion be vision and life threatening. An overview of common and rare conditions affecting the eyelids and a conceptual approach has been described earlier. When the diagnosis is in doubt or when extensive reconstruction or nonsurgical treatment is being considered, an incisional biopsy of the lesion for histopathological confirmation is indicated, which has been described earlier.

Excision of lesions are often performed after an initial diagnosis has been established, thereby being therapeutic [1-3]. Not infrequently, it may be performed as both a diagnostic and therapeutic procedure, especially when preoperative clinical

Electronic supplementary material The online version of this chapter (https://doi.org/10.1007/978-3-030-187576_3) contains supplementary material, which is available to authorized users.

\section{G. Sundar $(\bowtie)$}

Orbit and Oculofacial Surgery/Ophthalmic Oncology, Department of Ophthalmology, National University Hospital, National University of Singapore, Singapore, Singapore

Department of Pediatrics, National University Hospital, Singapore, Singapore

e-mail: Gangadhara_sundar@nuhs.edu.sg

F. P. Manjandavida

Department of Oculoplasty and Ocular Oncology, Horus Specialty Eye Care, Bangalore, India diagnosis is certain, and reconstruction is straightforward with minimal morbidity. In malignant lesions, wide excisions are performed, which are usually therapeutic followed by reconstruction. Oncological principles for eyelid malignancy are the same as in other malignant neoplasms involving skin and adnexa. The surgical aim should be complete excision with adequate margin clearance to minimize recurrence, metastasis, and mortality. Therefore, clinically confirmed malignant eyelid tumors are often excised with margin control either with frozen section control or by Moh's micrographic surgery followed by formal histopathological confirmation with permanent fixed section [4-6]. Where frozen section facility is unavailable, a wider excision may be performed with margin control with permanent histology and secondary with delayed primary reconstruction after histopathological confirmation of clear margins. Moh's micrographic surgery is a good alternative where available which helps secure clear margins before a delayed primary reconstruction [7]. Conjunctival map biopsy is performed in the presence of suspected intraepithelial invasion of conjunctiva, especially in sebaceous gland carcinoma of eyelid [8].

On occasion, a therapeutic excision of an eyelid tumor, typically infiltrative and aggressive malignant neoplasms, e.g., sebaceous gland adenocarcinoma, melanoma, and Merkel cell carcinoma, may be combined with sentinel lymph node biopsy or a modified radical regional (cervical) lymph node 
dissection, with adjuvant external beam therapy. The surgeon should thus not only be aware of the indications, but also be familiar with various techniques of excision and reconstruction. They should preferably work in multidisciplinary teams comprising pathologists, head and neck surgeons, Moh's micrographic surgeons, medical and radiation oncologists. Reconstruction, when performed, should not only be functional but should also be esthetically acceptable, with minimal donor site and host site morbidity and minimal downtime.

In general, small benign lesions may be excised with maximal tissue preservation. Unless typical of inflammatory lesions like a chalazion, it is recommended to submit the excised lesions for histopathological examination. Superficial benign epidermal lesions, especially when diagnosis is certain, may also be managed with tissue destructive techniques, e.g., fulguration, electrodessication, etc. [2]
When malignant lesions are excised, a "no touch" technique should be employed to avoid host tissue seeding. Excision should be performed as precisely and delicately as possible with the least tissue destructive technique and maximal hemostasis. It is essential to respect and preserve the anatomical vital structures medial canthal tendon, lateral canthal tendon, levator aponeurosis, lacrimal sac, etc. The nature of the underlying lesion also determines the margin of resection, e.g., benign lesion, maximal skin and subcutaneous tissue sparing; basal cell carcinoma, minimal 2-4 mm margin depending on the morphological variants; squamous cell carcinoma/sebaceous gland adenocarcinoma, 4-5 mm margin; and melanoma, up to $10 \mathrm{~mm}$ margin is recommended as the current standard of care. The commonly used instruments in various excision techniques are shown in Fig. 3.1.

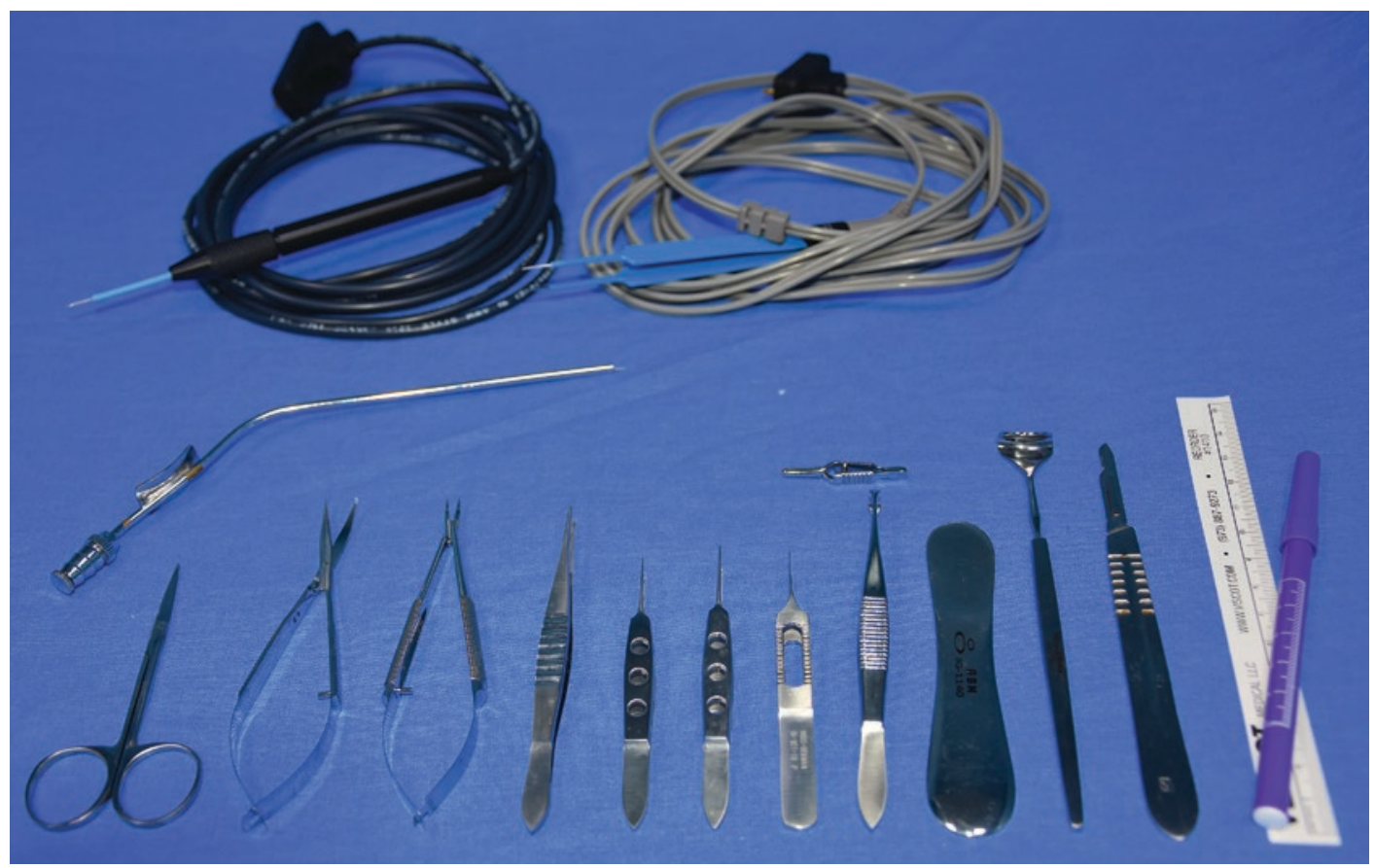

Fig. 3.1 Instrument tray. Instruments, starting lower left: 1, Metzenbaum scissors; 2, Westcott scissors; 3, Castroviejo needle holder; 4, tissue forceps; 5 and 6 , Bishop-Harmon forceps; 7, Adson tissue forceps; 8, Graefe forceps; 9, Jaeger lid plate; 10, Desmarres retrac- tor; 11, Bard-Parker knife handle; 12, fine tip marker and ruler; 13, Serrefine-Dienffenbach (bull dog clamps); 14, Frazier suction tip; 15 and 16, radiofrequency cautery monopolar and bipolar tips, 17, single and double skin hooks 


\section{Benign Lesions}

In general, benign lesions that are asymptomatic and insignificant cosmetically may be observed. When the clinical diagnosis is uncertain, early incisional or excisional biopsy are reasonable options. Most symptomatic benign lesions may be excised safely and easily, with precautions taken to avoid damage to vital ocular and adnexal structures, e.g., canthal tendons, lacrimal puncta and canaliculi, lacrimal sac, ocular surface, etc. Whenever possible a complete excision is recommended (Figs. 3.2, 3.3, 3.4, 3.5, 3.6, 3.7, 3.8 and 3.9, Tables 3.1 and 3.2, Video 3.1).

- Cystic lesions should be excised as to minimize inflammations and recurrences.
- Epidermal lesions are generally excised or fulgurated at the dermo-epidermal junction avoiding scarring, notching and need for wound repair (Video 3.2). Healing occurs by reepithelization of the raw area.

- Dermal lesions and dermal adnexal lesions will require skin excision in addition to complete removal of the lesion (Fig. 3.10a, b). The only exception is a compound or dermal nevus of the eyelid margin, when a shave excision is performed avoiding notching of the eyelid margins.

- Subcutaneous lesions are accessed through skin incisions along the relaxed tension line when possible or through preexisting eyelid creases.

Most eyelid surgeries are clean surgeries, and only topical cleansing of the eyelid with postoperative topical antibiotics is indicated.
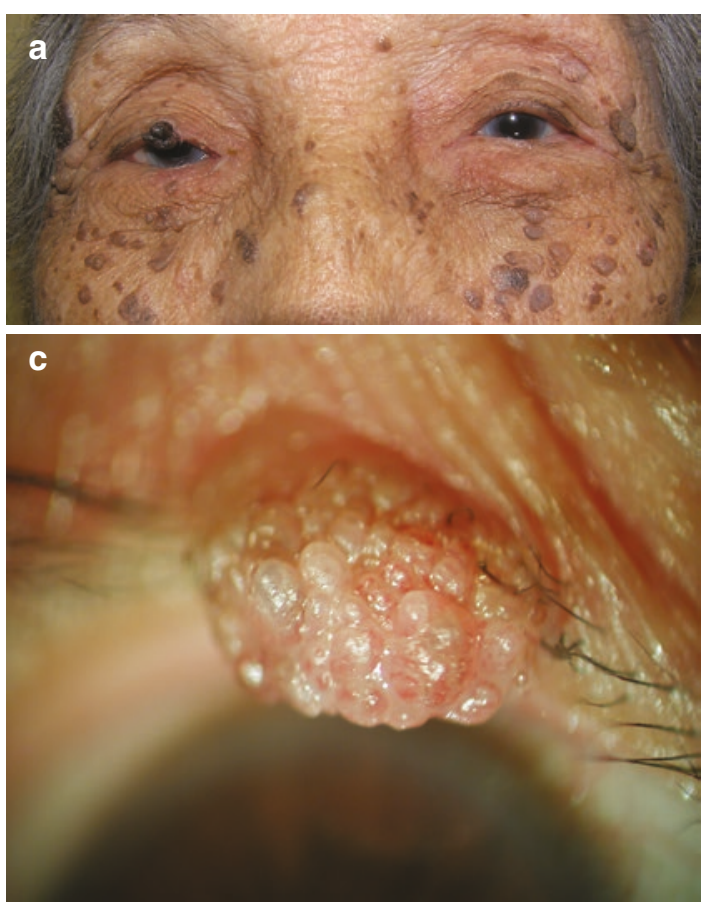

Fig. 3.2 (a) Seborrheic keratosis. (b) Fibroepithelial polyp. (c) Verruca vulgaris. (d) Acrochordon (skin tag)
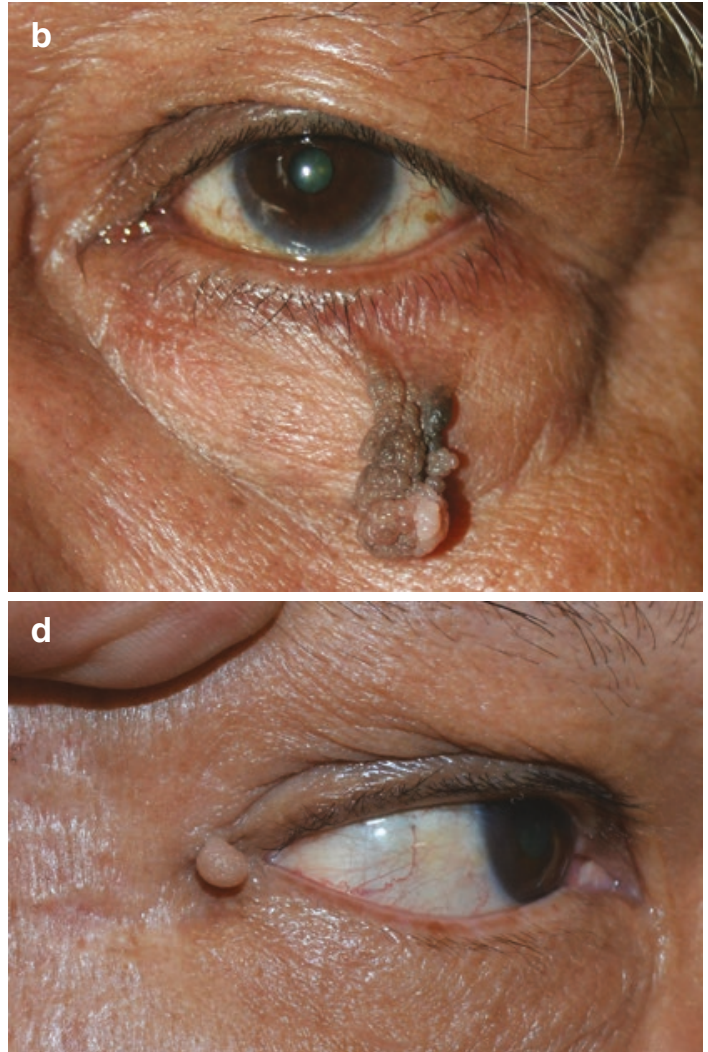

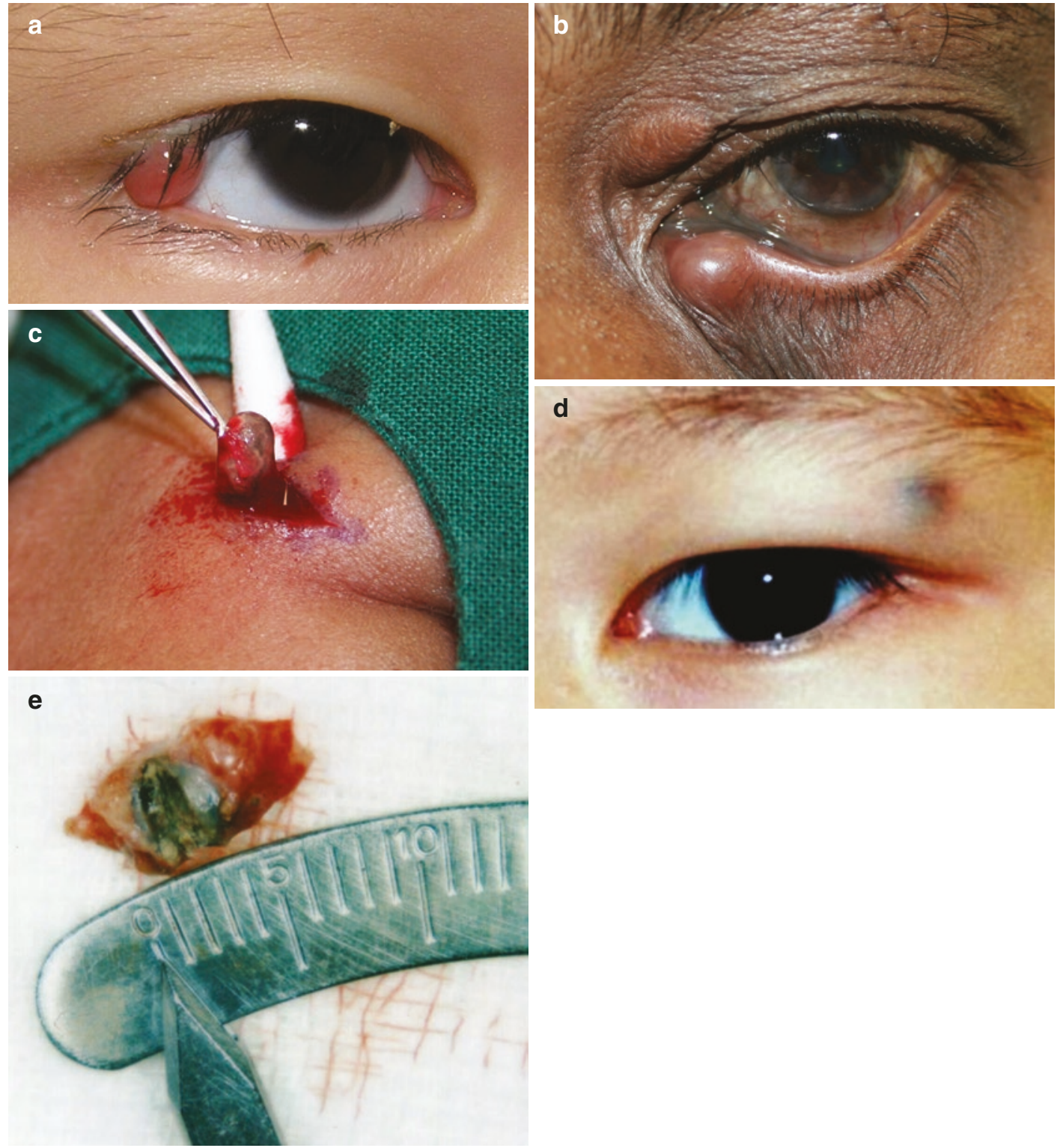

Fig. 3.3 (a) Chalazion with pyogenic granuloma. (b) Hidrocystoma Trichoepithelioma. (c) Complete excision. (d) Pilomatrixoma. (e) Excised specimen of pilomatrixoma

\section{Premalignant Lesions}

It is essential for the clinician to recognize potential premalignant lesions. Although these are more common in the Caucasian population, they may present in all ethnic groups and various skin types and pigmentation. In general, there should be a low threshold for performing a biopsy of suspicious lesions. At risk patients (e.g., actinic keratosis - squamous cell carcinoma, lentigo maligna - melanoma, xeroderma pigmentosa (Fig. 3.11) - basal cell carcinoma, squamous cell carcinoma, melanoma) should also be advised against ultraviolet light/sun exposure. Clinically evident change in size, thickness, color and vascularity may indicates malignant transfor- 

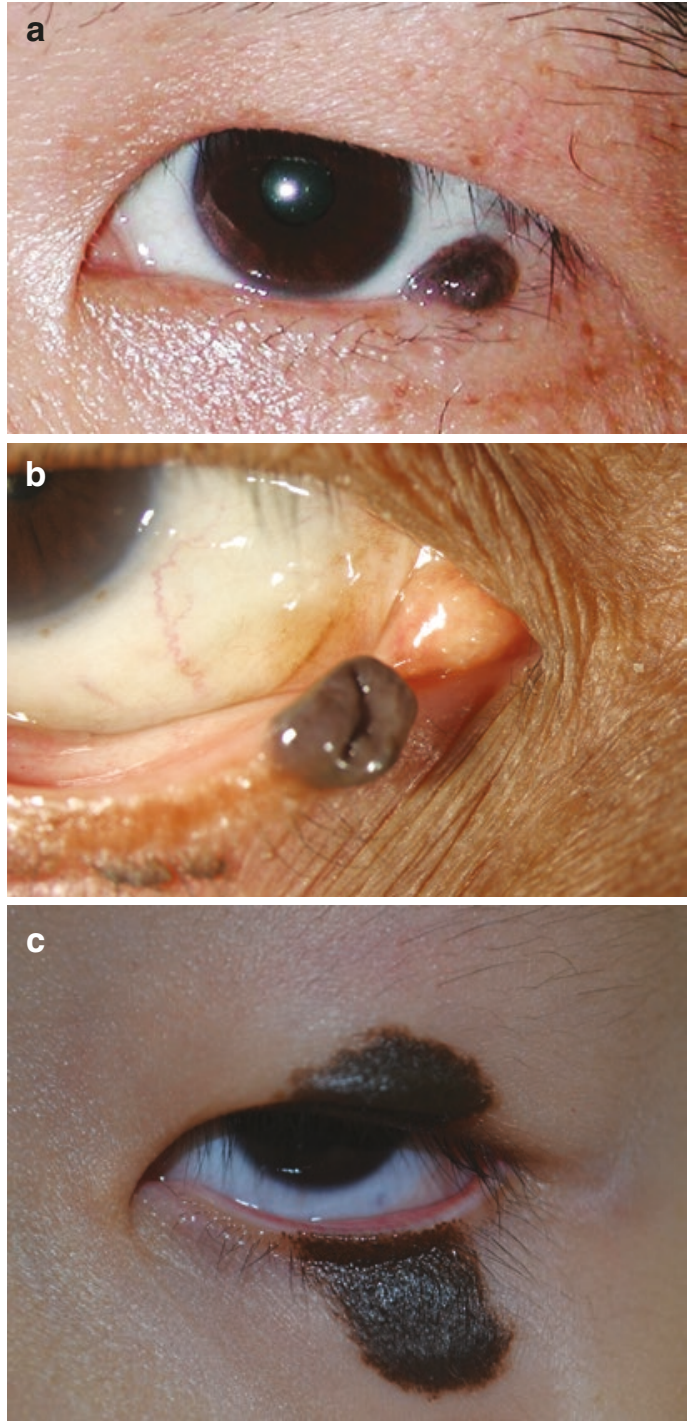

Fig. 3.4 (a) Eyelid margin pigmented nevus. (b) Peripunctal nevus. (c) Kissing nevus

mation, which may need surgical intervention (Figs. 3.11 and 3.12, Table 3.3).

\section{Malignant Eyelid Tumors}

In general, malignant lesions of the eyelids and periocular region are far less common than benign lesions [9]. While basal cell carcinomas are the most common in all ethnic groups, occurring primarily in sun-exposed areas, the prevalence of squamous cell carcinomas [10] and sebaceous gland adenocarcinomas are different between the Caucasian and the Asian populations. In eyelid malignancies other than basal cell carcinoma, regional lymph nodes, and systemic screening is mandated clinically and preferably by imaging as well. The decision to perform wide excision biopsy with clear margins, regional lymph node/ sentinel node biopsy (sebaceous gland adenocarcinoma, melanoma, Merkel cell carcinoma, etc.), cryotherapy of the edges, and ocular surface map biopsy (Sebaceous gland adenocarcinoma) depends on the nature of the primary malignancy. Some salient differences and some examples are shown in Table 3.4 (Figs. 3.13, 3.14, 3.15, 3.16, $3.17,3.18,3.19,3.20,3.21,3.22$ and 3.23).

\section{Basal Cell Carcinoma (BCC)}

Basal cell carcinomas are the most common malignant neoplasms of the eyelids and the face, globally. While most are sporadic and related to sun exposure especially in Caucasians of the lower Fitzpatrick skin types, they are seen in all ethnic and geographical regions with minor variations. Early lesions, typically nodular, are either ignored or misdiagnosed unless lesions are routinely sent for histopathological examination. In pigmented races, a pigmented form of $\mathrm{BCC}$ is often mistaken for a melanoma (Fig. 3.24). While the common type is a nodular or noduloulcerative type, rare forms include the morpheaform, infiltrative BCC (Fig. 3.25) or even the multicentric or superficial basal cell carcinoma. The latter are often diagnosed late and managed poorly as obtaining clear margins are difficult with local excision.

When localized, small and early, a simple excision with margin of $2-3 \mathrm{~mm}$ with frozen section control will suffice with primary reconstruction. Lid margin lesions will require a full thickness block resection (and not wedge resection) ideally under frozen section control with primary reconstruction [11]. Principles of wound healing and reconstruction include the laissez-faire technique, use of adjacent (eyelid, cheek, forehead) or regional flaps/grafts. 

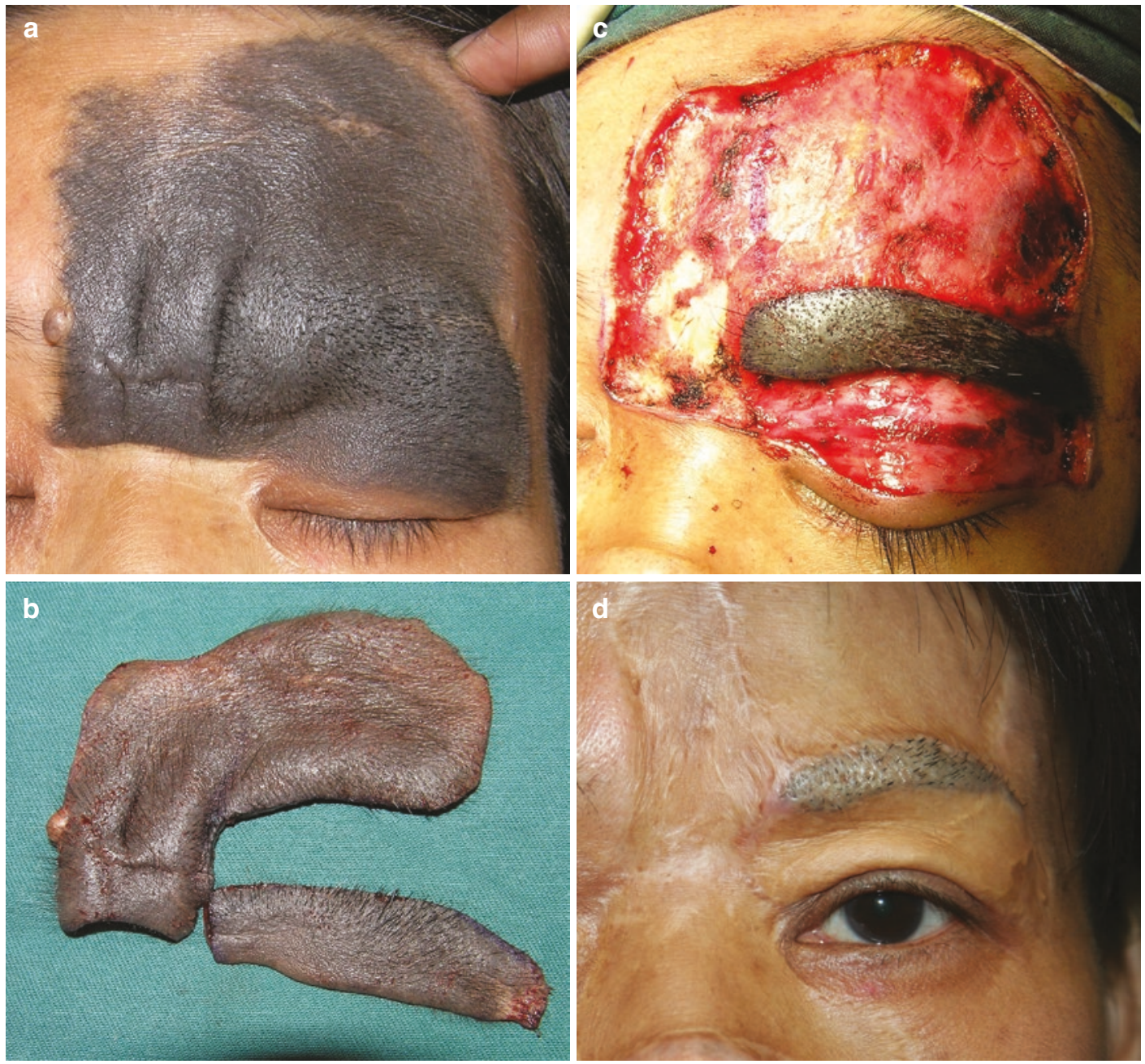

Fig. 3.5 (a) Giant hairy nevus. (b) Excised lesion of giant hairy nevus. (c) Post-excision with eyebrow preservation. (d) Post-reconstruction with suprapubic skin graft and laser treatment for eyebrow

Large lid margin defects may require complex reconstruction using either composite graft-flap techniques or lid sharing procedures and are discussed in detail in the following chapter. Large extensive and inoperable lesions away from the globes may be amenable to external beam radiation [12]. While it may obtain tumor control, tissue destruction is not often addressed by this modality of treatment. In the recent years, extensive and invasive basal cell carcinomas have been shown to be responsive to targeted therapy with hedgehog pathway inhibitors and, may be considered for extensive, recurrent and the rare metastatic lesions [13].

\section{Squamous Cell Carcinoma (SCC)}

Less frequent, but more challenging to diagnose and manage are SCC of the eyelid and adnexa. They are typically more common among the light pigmented races and those with predisposing conditions like actinic keratosis and xeroderma pigmentosa. While typi- 

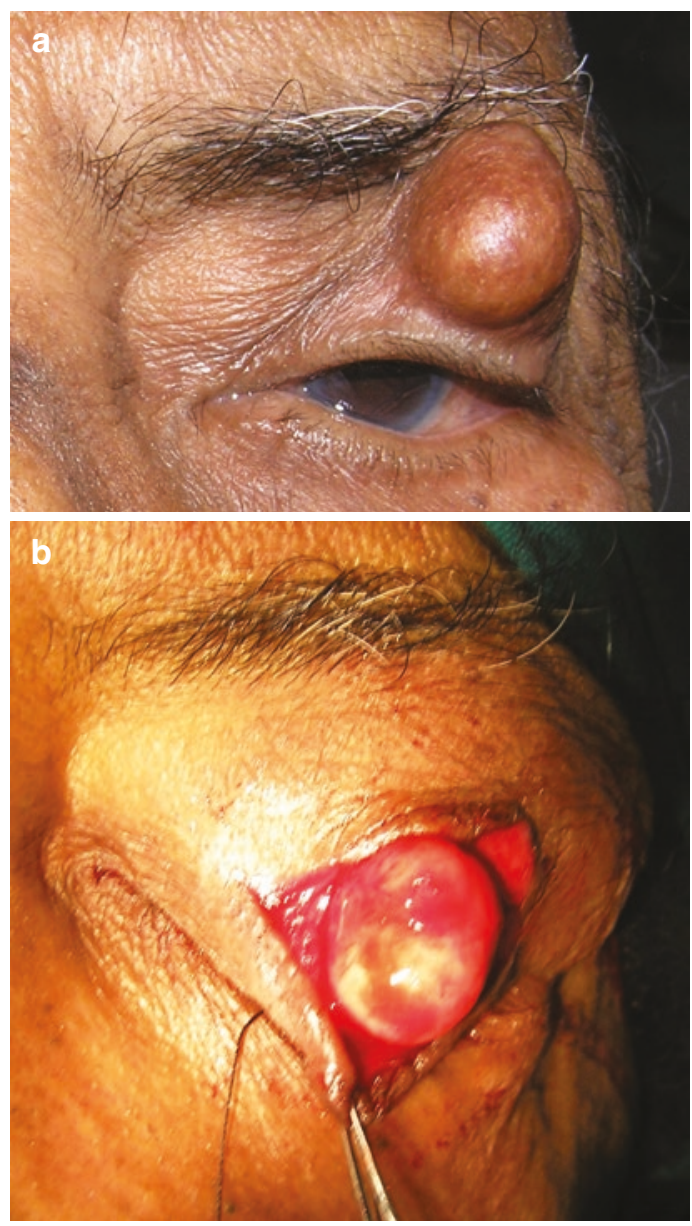

Fig.3.6 (a) Epidermal cyst. (b) Dissected epidermal cyst cal presentations are easily suspected, atypical presentations often result in late diagnosis and thus delay in management with a poorer prognosis [10]. Principles of management include wide excision with 3-4 $\mathrm{mm}$ margins under frozen section control, followed by reconstruction or Moh's micrographic surgery if available. Extensive lesions, deeper invasion, positive margins and inoperable lesions may
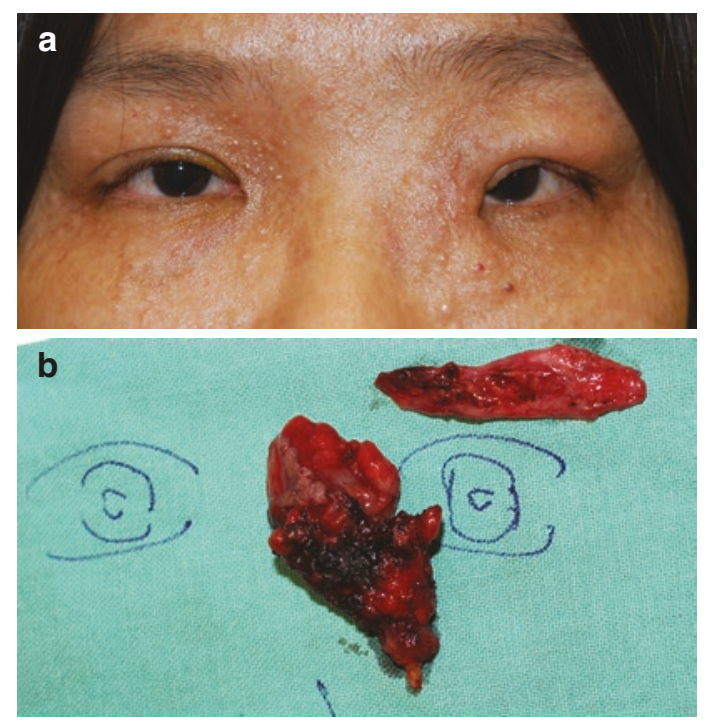

Fig. 3.8 (a) Neurofibroma. (b) Excised neurofibroma (templet method)
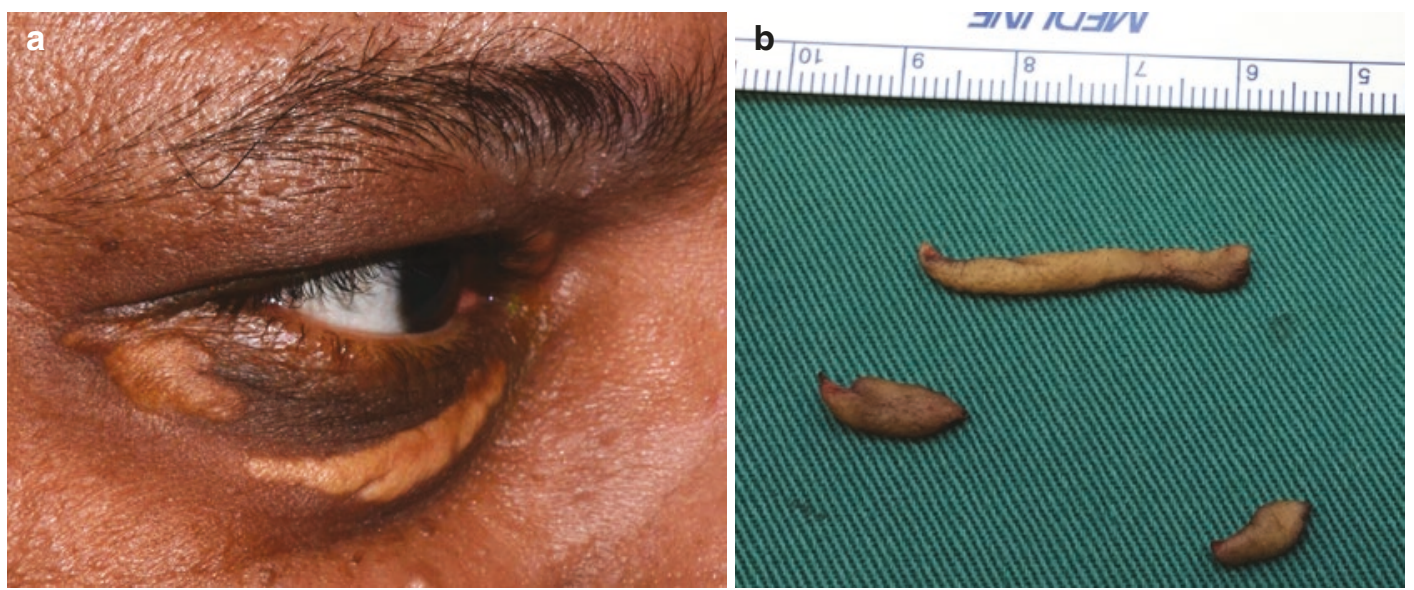

Fig. 3.7 (a) Eyelid xanthelasma. (b) Xanthelasma post-excision 

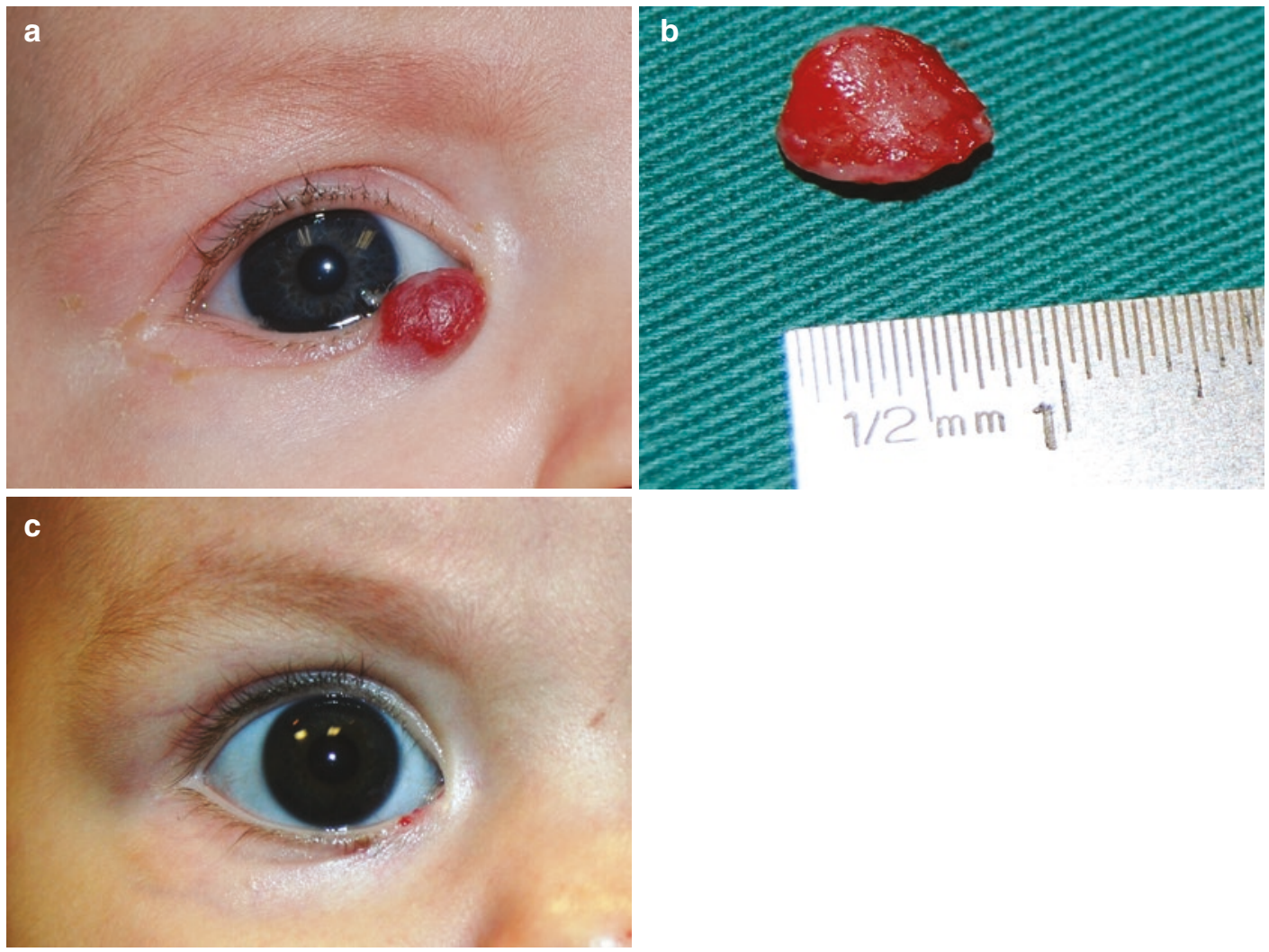

Fig. 3.9 (a) Partially involuted infantile hemangioma. (b) Excised partially involuted infantile hemangioma. (c) Postoperative image

Table 3.1 Spectrum of anesthetic techniques for various lesions of the eyelid and ocular adnexa

\begin{tabular}{|c|c|c|c|}
\hline Type of anesthesia & Principle & Typical indication & Technique \\
\hline None & $\begin{array}{l}\text { Brief, momentary, simple } \\
\text { procedure }\end{array}$ & $\begin{array}{l}\text { Acrochordons (skin tags), } \\
\text { pedunculated verruca }\end{array}$ & - \\
\hline Topical & $\begin{array}{l}\text { Superficial epidermal, sessile, } \\
\text { multiple lesions }\end{array}$ & $\begin{array}{l}\text { Syringomas, seborrheic } \\
\text { keratosis, etc. }\end{array}$ & $\begin{array}{l}\text { Topical lidocaine - } \\
\text { prilocaine application } \\
\text { with occlusive dressing } \\
\text { for } 15-20 \mathrm{~min}\end{array}$ \\
\hline \multirow{3}{*}{$\begin{array}{l}\text { Local/infiltrative } \\
\text { (lidocaine with } \\
\text { epinephrine, with or } \\
\text { without bupivacaine) }\end{array}$} & Nerve blocks & \multirow{3}{*}{$\begin{array}{l}\text { Larger eyelid lesions, } \\
\text { planned reconstruction }\end{array}$} & \multirow{3}{*}{$\begin{array}{l}\text { Frontal nerve block, } \\
\text { infraorbital nerve block, } \\
\text { infraorbital fan block etc. }\end{array}$} \\
\hline & Regional blocks & & \\
\hline & Fan blocks & & \\
\hline General anesthesia & $\begin{array}{l}\text { Extensive resections/ } \\
\text { reconstruction, regional lymph } \\
\text { node dissection, distal donor } \\
\text { site harvesting, uncooperative } \\
\text { patients }\end{array}$ & $\begin{array}{l}\text { Exenteration, extensive } \\
\text { reconstruction, cervical } \\
\text { lymph node dissection, } \\
\text { etc. }\end{array}$ & \\
\hline
\end{tabular}


Table 3.2 Principles of management: benign eyelid lesions

\begin{tabular}{|c|c|}
\hline Type of lesion & Principles of management \\
\hline \multicolumn{2}{|l|}{ Epidermal lesions } \\
\hline Seborrheic keratosis (Fig. 3.2a) & Observation, electrodessication, cautery with curettage \\
\hline \multicolumn{2}{|l|}{ Pseudoepitheliomatous hyperplasia } \\
\hline Fibroepithelial polyp (Fig. 3.2b) & Simple excision \\
\hline Verruca vulgaris (Fig. 3.2c) & Excision with no touch technique \\
\hline Acrochordons or skin tags (Fig. 3.2d) & Snip excision (Video 3.1) \\
\hline \multicolumn{2}{|l|}{ Benign adnexal tumors } \\
\hline Hordeolum internum & Systemic antibiotics, warm compresses \\
\hline Hordeolum externum & Lash epilation, pus expression \\
\hline $\begin{array}{l}\text { Chalazion: without or with pyogenic granuloma, } \\
\text { chalazion externum (Fig. } 3.3 \mathrm{a} \text { ) }\end{array}$ & $\begin{array}{l}\text { Incision, curettage, subconjunctival steroid injection, } \\
\text { pyogenic granuloma excision }\end{array}$ \\
\hline Sebaceous adenoma & Excision \\
\hline \multicolumn{2}{|l|}{ Eccrine sweat gland origin } \\
\hline Eccrine hidrocystoma & Marsupialization, complete excision \\
\hline Syringoma & Chemical peel, surface treatment \\
\hline Pleomorphic adenoma & Excision \\
\hline \multicolumn{2}{|l|}{ Apocrine sweat gland origin } \\
\hline Apocrine hidrocystoma & Marsupialization, complete excision \\
\hline \multicolumn{2}{|l|}{ Hair follicle origin } \\
\hline Trichoepithelioma (Fig. 3.3b) & Complete excision (Fig. 3.3c) \\
\hline Trichofolliculoma & Excision \\
\hline Tricholemmoma & Excision \\
\hline Pilomatrixoma (Fig. 3.3d) & Excision (Fig. 3.3e) \\
\hline \multicolumn{2}{|l|}{ Benign melanocytic lesions } \\
\hline \multicolumn{2}{|l|}{ Lid margin involving- } \\
\hline Single margin involving (Fig. 3.4a) & Shave excision \\
\hline Peripunctal nevi (Fig. 3.4b) & Limited excision with punctal preservation \\
\hline Kissing nevi (Fig. 3.4c) & Observation, excision with preservation of lid margin \\
\hline \multicolumn{2}{|l|}{ Non-lid margin involving nevi } \\
\hline Simple nevi & \multirow{3}{*}{$\begin{array}{l}\text { Observation, excision with skin grafting, pigment laser } \\
\text { treatments }\end{array}$} \\
\hline Hairy nevi & \\
\hline Giant nevi (Fig. 3.5a-d) & \\
\hline Freckle & \multirow[t]{5}{*}{ Observation, pigment laser applications } \\
\hline Lentigo simplex & \\
\hline Solar lentigo & \\
\hline Blue nevus & \\
\hline Dermal melanocytosis & \\
\hline \multicolumn{2}{|l|}{ Others } \\
\hline $\begin{array}{l}\text { Cysts (Fig. } 3.6 a \text { ): Epidermal cyst, implantation cysts, } \\
\text { inclusion cysts, dermal adnexal cysts }\end{array}$ & Excision with intact cyst (Fig. 3.6b) \\
\hline Xanthogranuloma & Excision \\
\hline Xanthelasmata (Fig. 3.7a) & Excision (Fig. 3.7b) with primary wound closure \\
\hline Neurofibromas (Fig. 3.8a) & Excision (template technique) (Fig. 3.8b) \\
\hline Capillary hemangioma (Fig. 3.9a-c) & $\begin{array}{l}\text { Observation, systemic beta blockers, systemic/ } \\
\text { intralesional steroids, excision }\end{array}$ \\
\hline
\end{tabular}



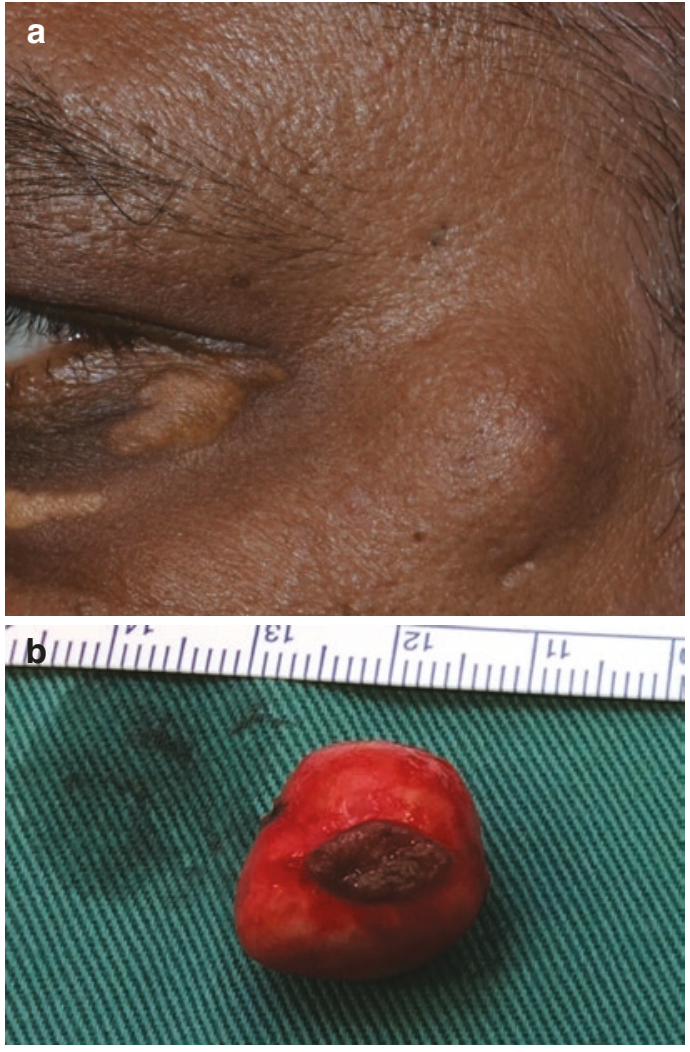

Fig. 3.10 (a) Dermal adnexal cyst. (b) Excised dermal adnexal cyst

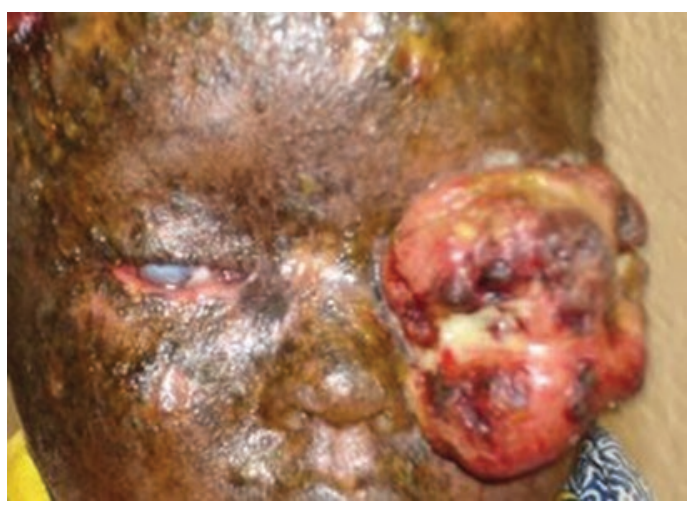

Fig. 3.11 Xeroderma pigmentosa

be candidates for radiation therapy. Epidermal growth factor receptor (EGFR) inhibitors have shown promising results recently [13].

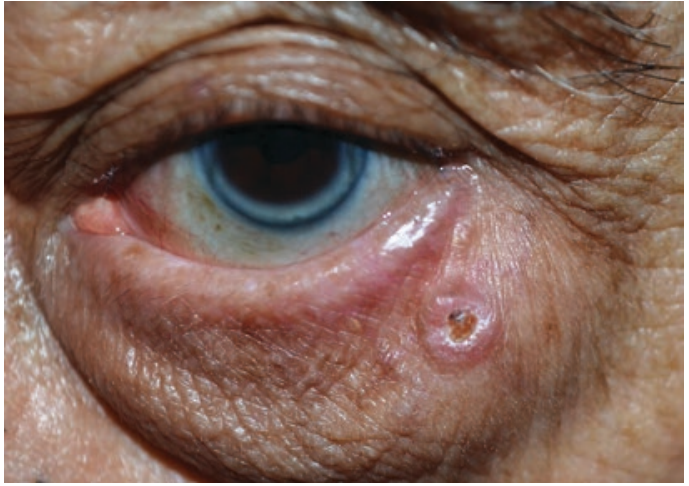

Fig. 3.12 Keratoacanthoma

Table 3.3 Principles of management: premalignant/in situ malignant eyelid lesions

\begin{tabular}{l|l}
\hline Type of lesion & Principles of management \\
\hline Actinic keratosis & $\begin{array}{l}\text { Observation with serial } \\
\text { follow-up, biopsy of } \\
\text { suspicious lesions }\end{array}$ \\
\hline Lentigo maligna & $\begin{array}{l}\text { Observation with serial } \\
\text { follow-up, biopsy of } \\
\text { suspicious lesions }\end{array}$ \\
\hline $\begin{array}{l}\text { Keratoacanthoma } \\
\text { (Fig. 3.12) }\end{array}$ & Excision biopsy \\
\hline $\begin{array}{l}\text { Xeroderma } \\
\text { pigmentosa (Fig. 3.11) }\end{array}$ & $\begin{array}{l}\text { Close observation and } \\
\text { biopsy of suspicious lesions }\end{array}$ \\
\hline
\end{tabular}

\section{Sebaceous Gland Carcinoma (SGC)}

These are far more common among Asians, being increasingly recognized compared to the past when they were either misdiagnosed as squamous cell carcinomas or even chronic blepharoconjunctivitis $[14,15]$. Most commonly arising from the meibomian glands situated in the posterior lamellae, they may even arise from the Zeis glands and caruncle. Seen most commonly in the upper eyelid, involving the tarsal meibomian glands, they are notorious for pagetoid spread with skip lesions rendering frozen sections less reliable and frequently involve the ocular surface. Late presentations may also present with anterior orbital extension, regional (preauricular and cervical lymph nodes) spread, or even systemic metastasis [16]. 
Table 3.4 Principles of management: malignant eyelid lesions

\begin{tabular}{|c|c|}
\hline Type of lesion & Principles of management \\
\hline \multirow[t]{4}{*}{$\begin{array}{l}\text { Basal cell carcinoma (Figs. } 3.13 \mathrm{a}-\mathrm{c} \text {, } \\
3.14 \mathrm{a}, \mathrm{b} \text { and } 3.15 \mathrm{a}-\mathrm{d})\end{array}$} & $\begin{array}{l}\text { Wide excision with } 2-4 \mathrm{~mm} \text { margin, frozen section control, primary } \\
\text { reconstruction }\end{array}$ \\
\hline & Moh's micrographic excision with delayed primary reconstruction. \\
\hline & External beam radiation (inoperable lesions) \\
\hline & Hedgehog pathway inhibitors (for inoperable, non-radiatable BCCs) \\
\hline \multirow[t]{6}{*}{ Squamous cell carcinoma (Fig. 3.16) } & $\begin{array}{l}\text { Wide excision 3-4 mm margins, frozen section control, primary } \\
\text { reconstruction }\end{array}$ \\
\hline & Moh's micrographic excision with delayed primary reconstruction \\
\hline & Radiotherapy \\
\hline & Exenteration (extensive eyelid lesion with orbital invasion) \\
\hline & Imiquimod therapy (superficial, extensive, recurrent SCC) \\
\hline & Epidermal growth factor receptor inhibitors \\
\hline \multirow[t]{3}{*}{$\begin{array}{l}\text { Sebaceous gland adenocarcinoma } \\
\text { (Figs. } 3.17 \mathrm{a}-\mathrm{c} \text { and } 3.18 \mathrm{a}-\mathrm{e} \text { ) }\end{array}$} & $\begin{array}{l}\text { Wide excision with wide margins }(4 \mathrm{~mm}) \text {, under frozen section control } \\
\text { (less reliable), cryotherapy of edges, conjunctival map biopsy, primary } \\
\text { reconstruction. Sentinel lymph node biopsy in lesions }>10 \mathrm{~mm} \text { in size, } \\
\text { regional lymph node dissection (spread, PET-CT positive) }\end{array}$ \\
\hline & Chemoreduction with local excision \\
\hline & Orbital exenteration \\
\hline Mucinous carcinoma (Fig. 3.19a-d) & Excision with wide margins, frozen section control, primary reconstruction \\
\hline \multirow[t]{4}{*}{ Merkel cell carcinoma (Fig. 3.20a, b) } & Wide excision with $4 \mathrm{~mm}$ margins under frozen section \\
\hline & Moh's micrographic excision \\
\hline & Sentinel lymph node biopsy \\
\hline & Regional lymph node dissection, adjuvant chemotherapy, radiotherapy \\
\hline Melanoma (Fig. 3.21a, b) & $\begin{array}{l}\text { Wide excision ( } 10 \mathrm{~mm} \text { if possible), primary reconstruction, sentinel lymph } \\
\text { node biopsy, orbital exenteration, palliative therapy }\end{array}$ \\
\hline Lymphoma (Fig. 3.22) & Radiation and chemotherapy \\
\hline Metastasis (Fig. 3.23) & External beam radiotherapy, targeted therapy where applicable \\
\hline
\end{tabular}

Principles of management include preoperative systemic evaluation to rule out regional and systemic spread followed by wide excision with margin clearance of at least $4 \mathrm{~mm}$ [17] (Video 3.3). Frozen section control is challenging in the presence of conjunctival intraepithelial (pagetoid) spread. A few examples of eyelid sebaceous gland carcinoma excision and reconstruction are shown in Videos 3.4, 3.5, 3.6 and 3.7.

In the presence of clinically suspicious intraepithelial spread with conjunctival hyperemia (tarsal and/or bulbar) and lid margin thickening, a conjunctival map biopsy is indicated to ensure ocular surface is free of the tumor and guide further management if indicated [18]. The location of the map biopsy varies according to the clinical presentation. These include forniceal conjunctival (upper and lower), bulbar conjunc- tival (upper and lower), perilimbal conjunctival (four quadrants) and the caruncle. Invasion of the orbit is often considered an indication for orbital exenteration.

Recent evidence suggests a possible benefit of systemic "chemoreduction" minimizing the need for mutilating exenteration with early orbital invasion [19]. With obvious cervical node involvement, a modified radical lymph node dissection is often indicated. A recent trend toward sentinel lymph node biopsy (SNLB) is practiced in some centers around the world. SNLB is indicated in tumors that are clinically measured $>10 \mathrm{~mm}$ in size. Despite a better understanding, greater awareness and improved techniques, locoregional recurrences and distant metastases are not uncommon resulting in higher mortality compared to the above neoplasms. 

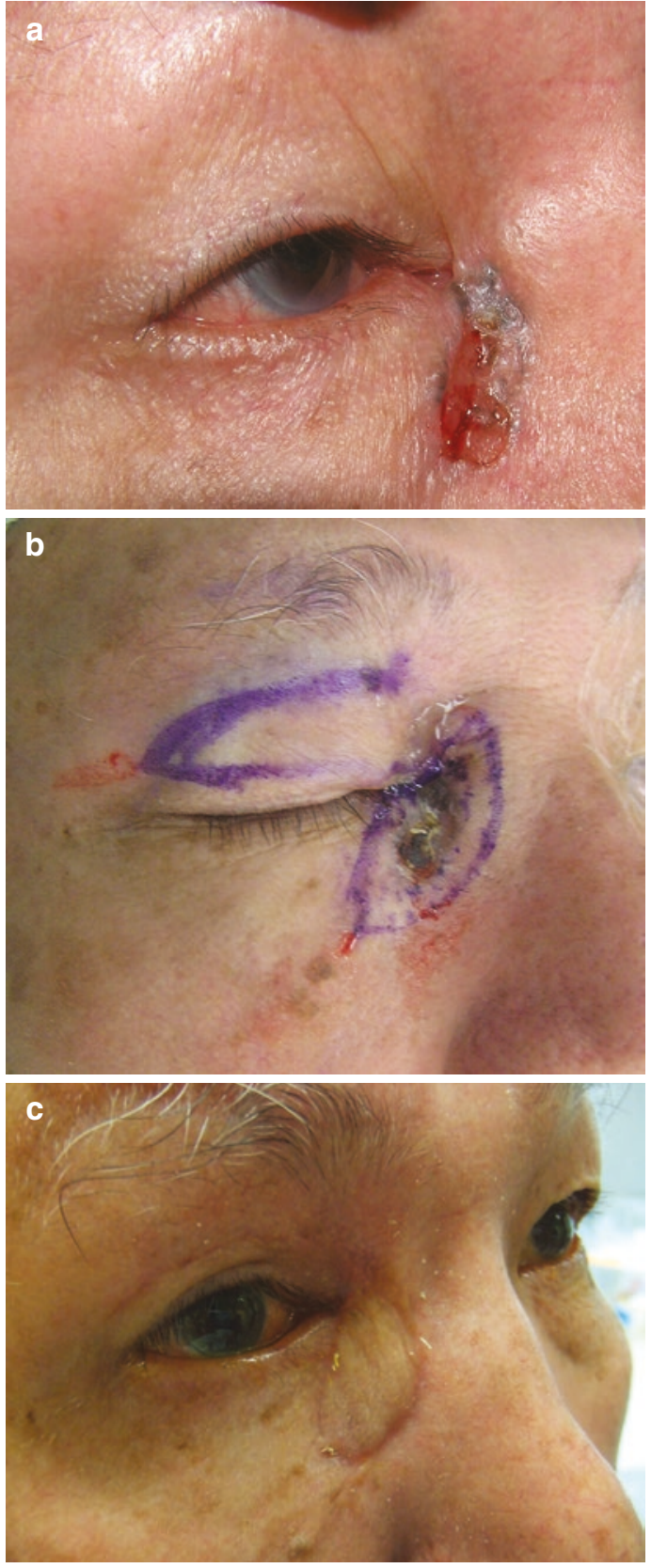

Fig. 3.13 (a) BCC at medial canthus. (b) BCC at medial canthus repaired with regional flap. (c) Postoperative image

\section{Eyelid Melanoma}

Melanomas of the eyelid are rare and may be either a nodular melanoma or superficial spreading melanoma (arising from a lentigo maligna), and
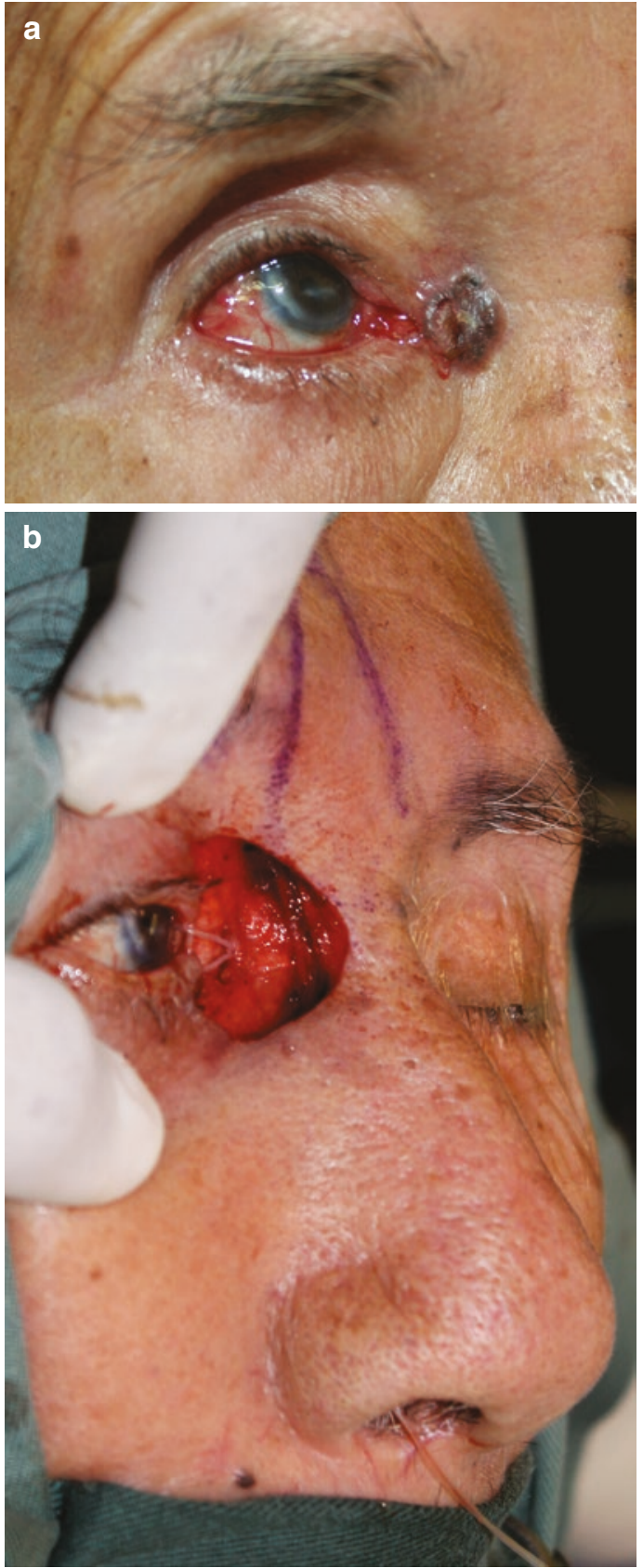

Fig. 3.14 (a) BCC at medial canthus. (b) Basal cell carcinoma medial canthus repaired with paramedian forehead flap. Note the reconstruction of lacrimal system

can be primary or secondary. They are commonly associated with a poorer prognosis as recurrence rates are high, and the presence of regional or systemic spread even at or soon after presentation. 

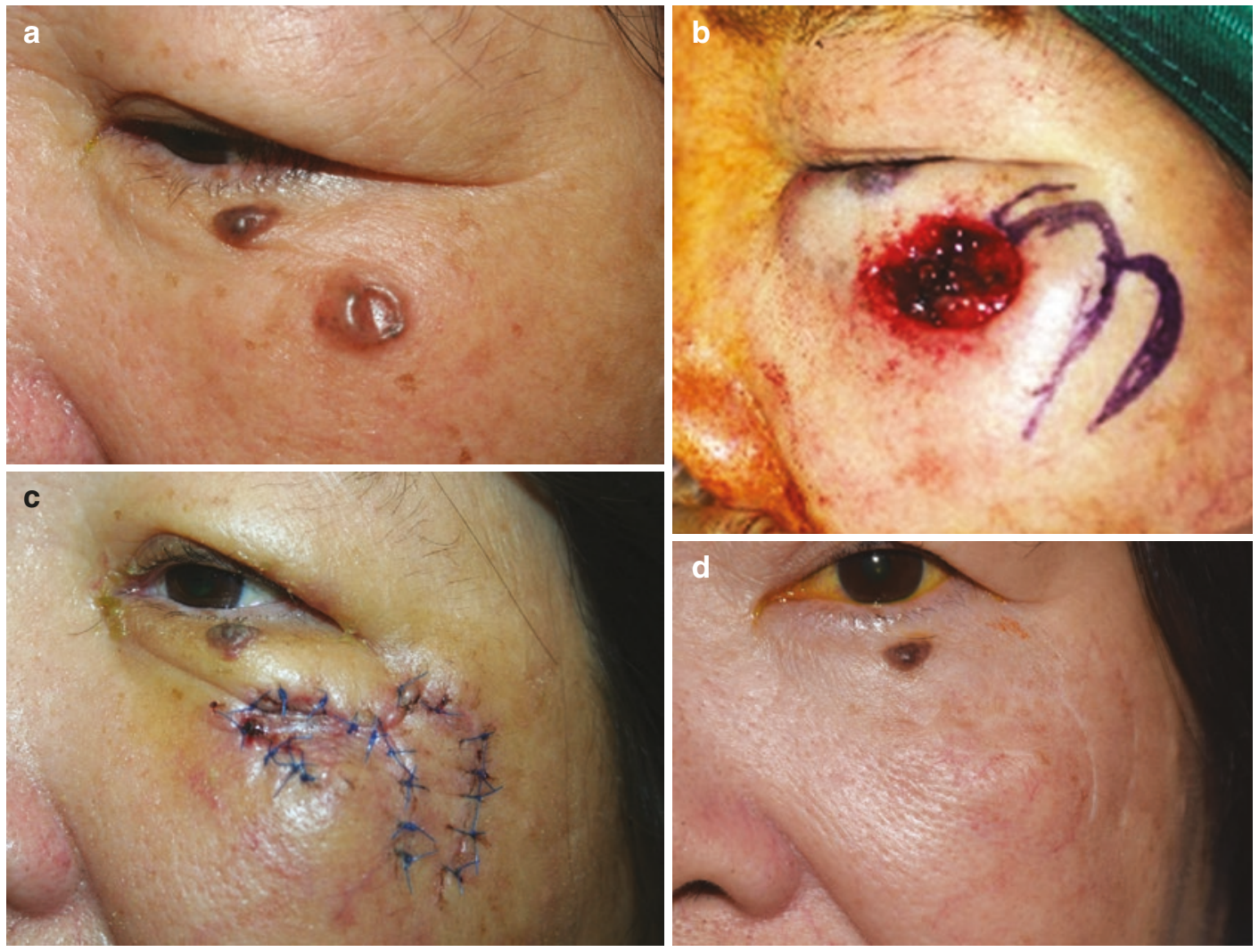

Fig. 3.15 (a) Basal cell carcinoma left cheek. (b) Basal cell carcinoma left cheek with markings for reconstruction. (c) Basal cell carcinoma left cheek post-reconstruction. (d) Postoperative image

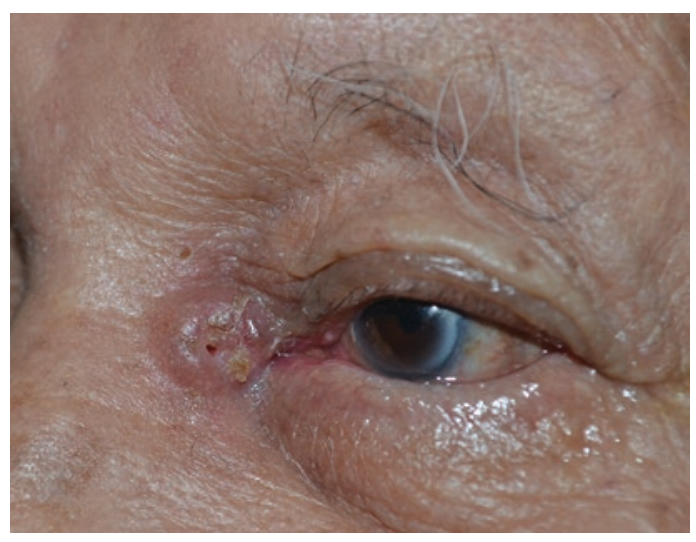

Fig. 3.16 Squamous cell carcinoma at medial canthus

In keeping with melanoma elsewhere, whenever possible a wide excision with at least $5-10 \mathrm{~mm}$ margin may be indicated, making reconstruction challenging [20]. Video 3.7 demonstrates management of lower eyelid melanoma. Histopathological features of lymphatic or vascular invasion, lesions $\geq 1 \mathrm{~mm}$ thick, $>1$ mitotic figure/high power field and/or ulceration and Breslow grading of more than 1000 microns are common indications for sentinel node biopsy and regional lymph node dissection. There is no role for cryotherapy with melanomas of the eyelid. When the systemic spread is present, the prognosis for life is usually guarded. The recent introduction of targeted therapy with BRAF inhibitors and MEK inhibitors in conjunctival melanoma is yet to be validated in eyelid melanomas.

\section{Merkel Cell Carcinoma}

These rare but aggressive neoplasms also commonly involve the upper eyelids and are often diagnosed as recurrent chalazia. Because of their late recognition and aggressive nature, they fre- 

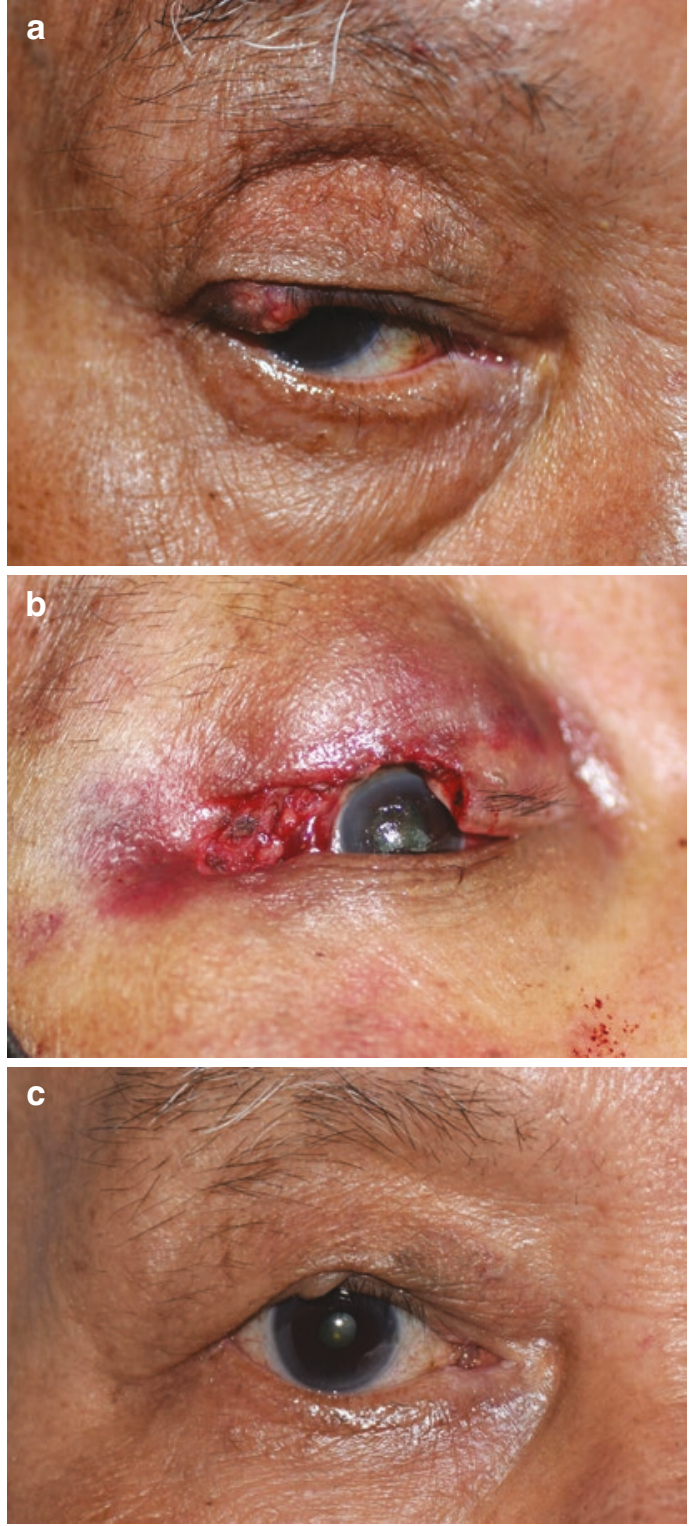

Fig. 3.17 (a) Sebaceous gland carcinoma Right upper eyelid. (b) Post-resection Sebaceous glands carcinoma. (c) 3-month postoperative follow-up image

quently spread regionally and even systemically, even at initial presentation resulting in early mortality. Localized lesions, after initial incisional biopsy, should undergo wide excision and reconstruction with sentinel node biopsy where possible. Radiotherapy and immuno-chemotherapy play an important role with regional and systemic spread, despite their guarded prognosis [21-23].

\section{Postoperative Care}

As in most surgeries, postoperative care is important to avoid complications such as infection, bleeding, and to maintain wound integrity especially with extensive reconstructions. Therefore, immediate postoperative wound care plays a major role.

- Local cleaning with 5-10\% povidone-iodine solution and topical antibiotic ointment is recommended 2-3 times per day starting the day after the surgery to prevent infection until 3 weeks.

- To avoid bleeding, the patient is advised to refrain from strenuous physical activities and avoid drugs that may prolong bleeding. Traditional medicines including gingko, garlic, ginseng, and even high doses of Vitamin E can alleviate bleeding tendencies.

- Postoperative swelling can be minimized with immediate use of ice packs that mostly subsides within 3 days postoperative.

\section{Follow-Up}

Despite meticulous surgical approach, recurrence may occur in eyelid tumors, be it benign or malignant. Unlike the benign variants, malignant eyelid tumors warrant strict follow up to detect early recurrence and metastasis. It includes postoperative follow-up at 1 week, 3 weeks, and 6 weeks. For the first year 3 monthly follow-up is recommended for lethal eyelid malignancies, followed by 6-monthly up to next 2 years and yearly thereafter lifelong. 

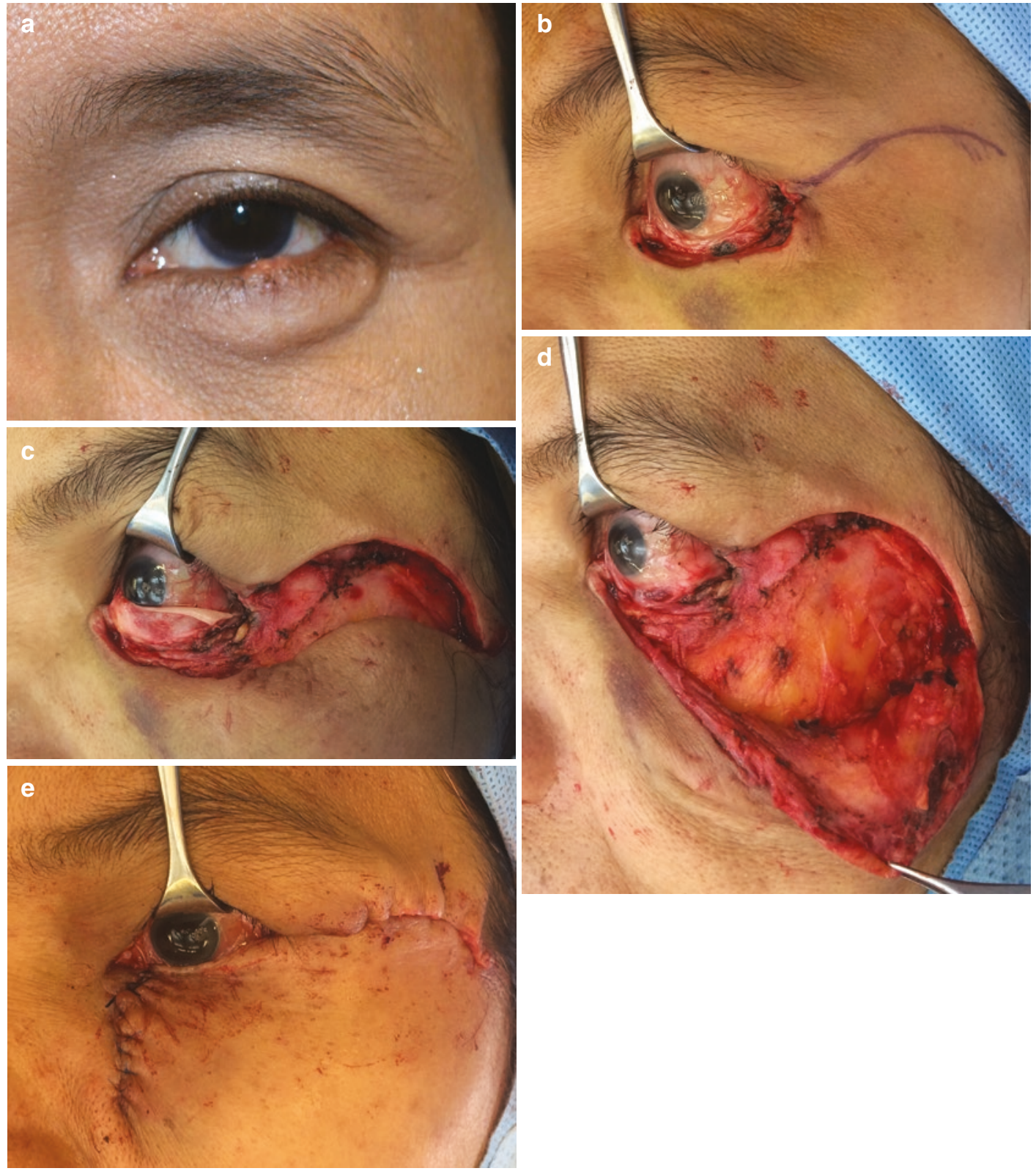

Fig. 3.18 (a) Sebaceous gland carcinoma lower eyelid. (b) Post-resection. (c) Posterior lamellar reconstruction with hard palate mucosal graft. (d) Cheek rotation flap. (e) Post-reconstruction

In summary, lesions of the eyelid may be benign (inflammatory, developmental or true neoplasms) or malignant. A high degree of clinical suspicion, incisional or excisional biopsy when suspected, regional and systemic assessment when indicated followed by tailored approaches to reconstruction and management are essential to deliver the most optimal outcome. Long-term follow-up is warranted in detecting early recurrence and metastasis in eyelid malignancies. 

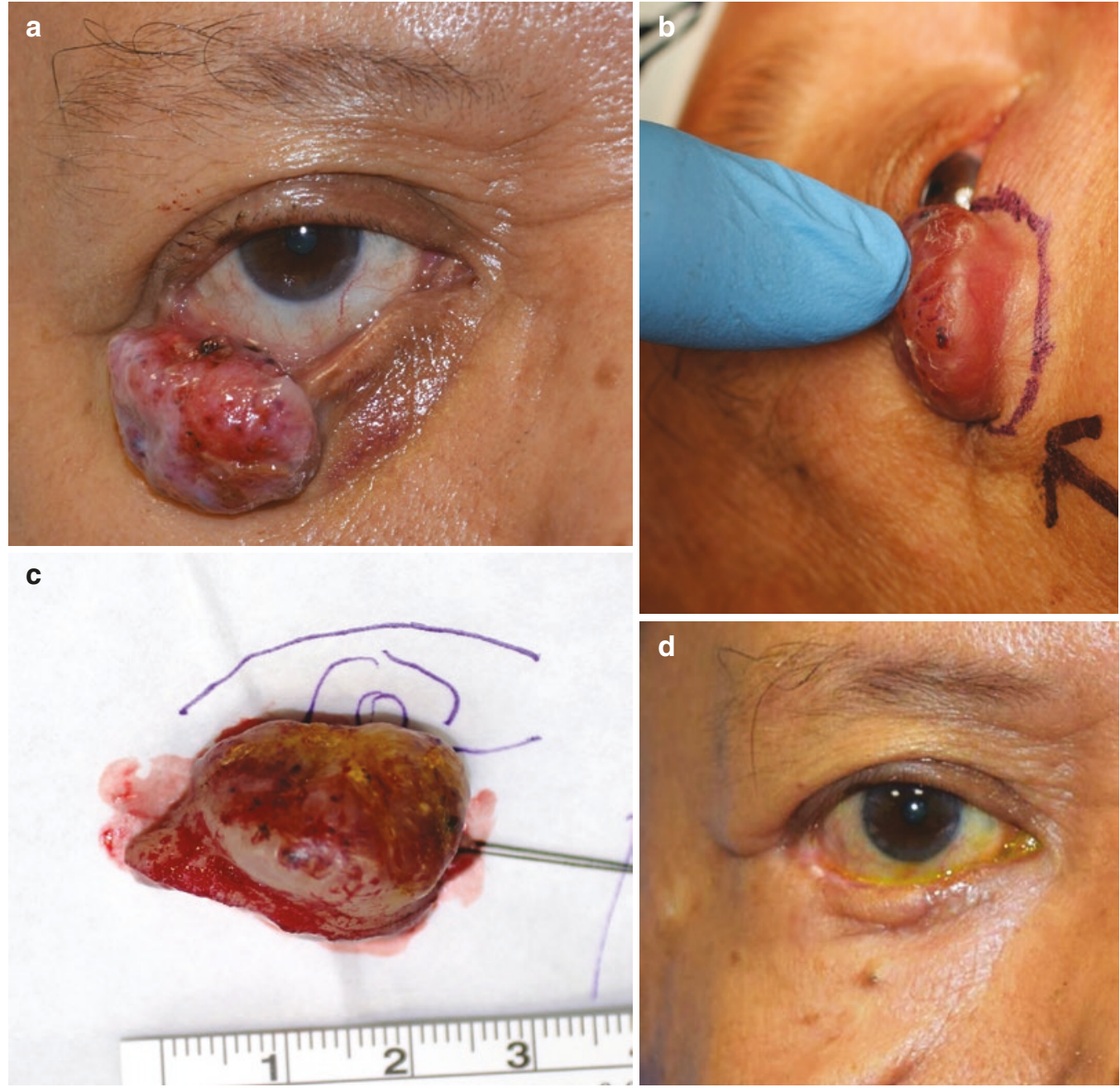

Fig. 3.19 (a) Mucinous carcinoma right lower eyelid. (b) Intraoperative marking with $4 \mathrm{~mm}$ margin. (c) Intraoperative specimen. (d) Late postoperative view
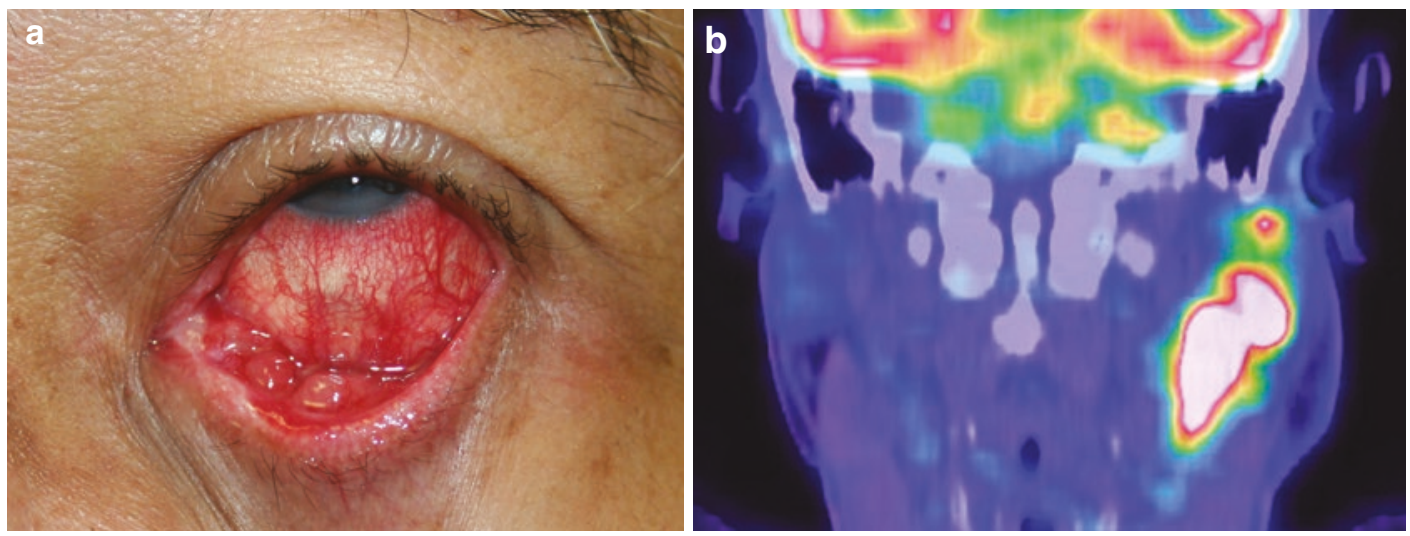

Fig. 3.20 (a) Merkel cell carcinoma. (b) PET-CT Merkel cell carcinoma with regional lymph node involvement 


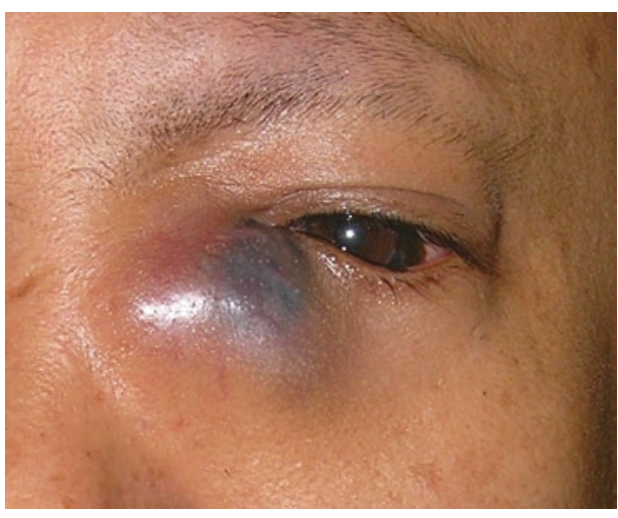

Fig. 3.21 Melanoma eyelid and medial canthus

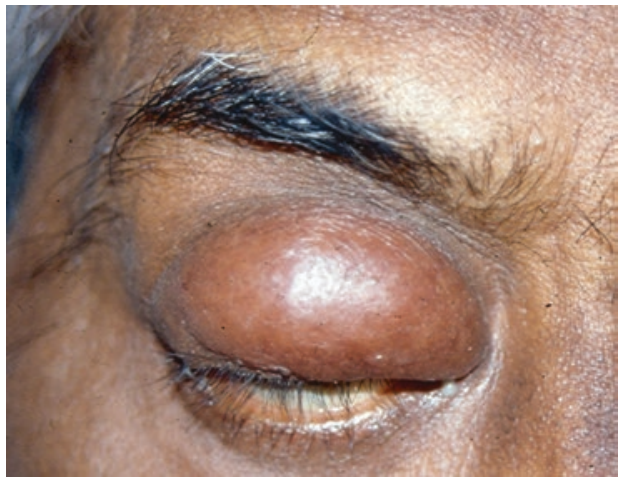

Fig. 3.22 Lymphoma involving eyelid

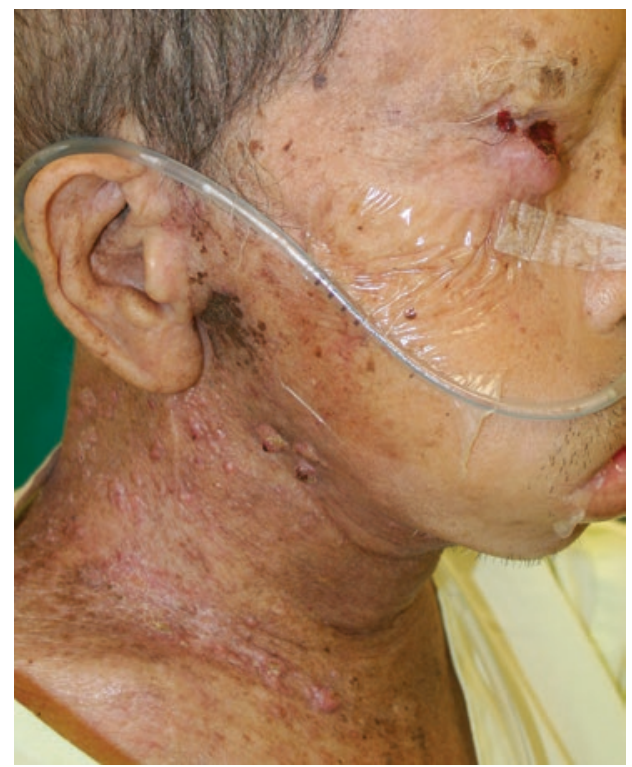

Fig. 3.23 Recurrent sebaceous gland carcinoma with loco-regional \& systemic spread

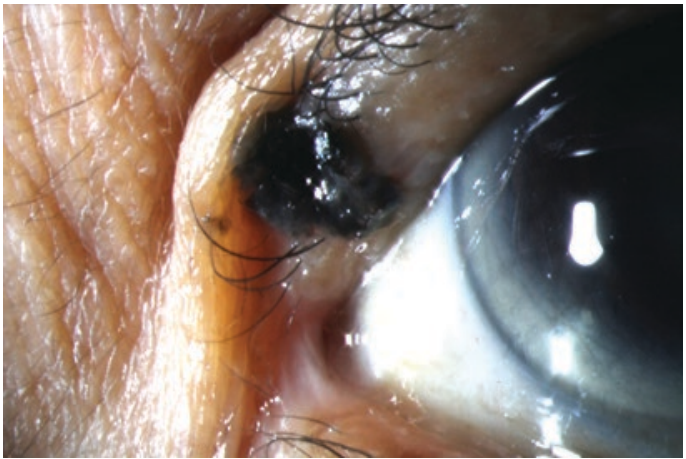

Fig. 3.24 Pigmented basal cell carcinoma referred as melanoma

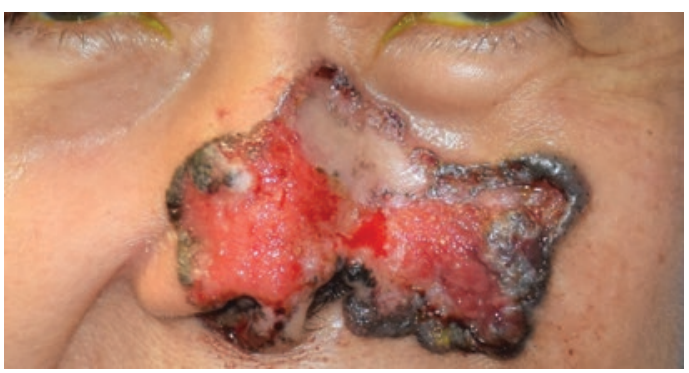

Fig. 3.25 Infiltrative basal cell carcinoma

Acknowledgment Videos 3. 4-3.7 have been included with contribution from Santosh G Honavar, MD, FACS, and Ankit Singh Tomar, MD, Ocular Oncology Service, Centre for Sight, Banjara Hills, Hyderabad, India.

\section{References}

1. Cook BE Jr, Bartley GB. Treatment options and future prospects for the management of eyelid malignancies: an evidence-based update. Ophthalmology. 2001;108(11):2088-98.

2. Bernardini FP. Management of malignant and benign eyelid lesions. Curr Opin Ophthalmol. 2006 Oct;17(5):480-4.

3. Rene C. Oculoplastic aspects of ocular oncology. Eye (Lond). 2013 Feb;27(2):199-207. https://doi. org/10.1038/eye.2012.243.

4. Gayre GS, Hybarger CP, Mannor G, Meecham W, Delfanti JB, Mizono GS, Guerry TL, Chien JS, Sooy CD, Anooshian R, Simonds R, Pietila KA, Smith DW, Dayhoff DA, Engman E, Lacy J. Outcomes of excision of 1750 eyelid and periocular skin basal cell and squamous cell carcinomas by modified en face frozen section margin-controlled technique. Int Ophthalmol Clin. 2009. Fall;49(4):97-110. 
5. Giordano Resti A, Sacconi R, Baccelli N, Bandello F. Outcome of 110 basal cell carcinomas of the eyelid treated with frozen section-controlled excision: mean follow-up over 5 years. Eur J Ophthalmol. 2014;24(4):476-82.

6. Mohs FE. Micrographic surgery for the microscopically controlled excision of eyelid cancers. Arch Ophthalmol. 1986;104(6):901-9.

7. While B, Salvi S, Currie Z, Mudhar HS, Tan $\mathrm{JH}$. Excision and delayed reconstruction with paraffin section histopathological analysis for periocular sebaceous carcinoma. Ophthalmic Plast Reconstr Surg. 2014;30(2):105-9.

8. McConnell LK, Syed NA, Zimmerman MB, Carter KD, Nerad JA, Allen RC. Shriver EM. An analysis of conjunctival map biopsies in sebaceous carcinoma. Ophthalmic Plast Reconstr Surg. 2017;33(1):17-21.

9. Cook BE Jr, Bartley GB. Epidemiologic characteristics and clinical course of patients with malignant eyelid tumors in an incidence cohort in Olmsted County, Minnesota. Ophthalmology. 1999;106(4):746-50.

10. Nemet AY, Deckel Y, Martin PA, Kourt G, Chilov M, Sharma V, Benger R. Management of periocular basal and squamous cell carcinoma: a series of 485 cases. Am J Ophthalmol. 2006;142(2):293-7.

11. Frank HJ. Frozen section control of excision of eyelid basal cell carcinomas: 8 1/2 years' experience. Br J Ophthalmol. 1989;73(5):328-32.

12. Rodriguez-Sains RS, Robins P, Smith B, Bosniak SL. Radiotherapy of periocular basal cell carcinomas: recurrence rates and treatment with special attention to the medical canthus. Br J Ophthalmol. 1988;72(2):134-8.

13. Yin VT, Pfeiffer ML, Esmaeli B. Targeted therapy for orbital and periocular basal cell carcinoma and squamous cell carcinoma. Ophthalmic Plast Reconstr Surg. 2013;29(2):87-92.

14. Watanabe A, Sun MT, Pirbhai A, Ueda K, Katori N, Selva D. Sebaceous carcinoma in Japanese patients: clinical presentation, staging and outcomes. $\mathrm{Br} \mathrm{J}$ Ophthalmol. 2013;97(11):1459-63.

15. Kaliki S, Ayyar A, Dave TV, Ali MJ, Mishra DK, Naik MN. Sebaceous gland carcinoma of the eyelid: clinicopathological features and outcome in Asian Indians. Eye (Lond). 2015;29(7):958-63.

16. Shields JA, Saktanasate J, Lally SE, Carrasco JR, Shields CL. Sebaceous carcinoma of the ocular region: the 2014 Professor Winifred Mao lecture. Asia Pac J Ophthalmol (Phila). 2015;4(4):221-7.

17. Brady KL, Hurst EA. Sebaceous carcinoma treated with Mohs micrographic surgery. Dermatol Surg. 2017;43(2):281-6.

18. Honavar SG, Shields CL, Maus M, Shields JA, Demirci H, Eagle RC Jr. Primary intraepithelial sebaceous gland carcinoma of the palpebral conjunctiva. Arch Ophthalmol. 2001;119(5):764-7.

19. Honavar SG. Sebaceous gland carcinoma: can we do better? Indian J Ophthalmol. 2018;66(9):1235-7.

20. Chan FM, O'Donnell BA, Whitehead K, Ryman W, Sullivan TJ. Treatment and outcomes of malignant melanoma of the eyelid: a review of 29 cases in Australia. Ophthalmology. 2007;114(1):187-92.

21. Herbert HM, Sun MT, Selva D, Fernando B, Saleh GM, Beaconsfield M, Collin R, Uddin J, Meligonis G, Leatherbarrow B, Ataullah S, Irion L, McLean CJ, Huilgol SC, Davis G, Sullivan TJ. Merkel cell carcinoma of the eyelid: management and prognosis. JAMA Ophthalmol. 2014;132(2):197-204.

22. Colombo F, Holbach LM, Jünemann AG, SchlötzerSchrehardt U, Naumann GO. Merkel cell carcinoma: clinicopathologic correlation, management, and follow-up in five patients. Ophthalmic Plast Reconstr Surg. 2000;16(6):453-8.

23. Stagner AM, Jakobiec FA. Updates on the molecular pathology of selected ocular and ocular adnexal tumors: potential targets for future therapy. Semin Ophthalmol. 2016;31(1-2):188-96.

Open Access This chapter is licensed under the terms of the Creative Commons Attribution 4.0 International License (http://creativecommons.org/licenses/by/4.0/), which permits use, sharing, adaptation, distribution and reproduction in any medium or format, as long as you give appropriate credit to the original author(s) and the source, provide a link to the Creative Commons license and indicate if changes were made.

The images or other third party material in this chapter are included in the chapter's Creative Commons license, unless indicated otherwise in a credit line to the material. If material is not included in the chapter's Creative Commons license and your intended use is not permitted by statutory regulation or exceeds the permitted use, you will need to obtain permission directly from the copyright holder. 